
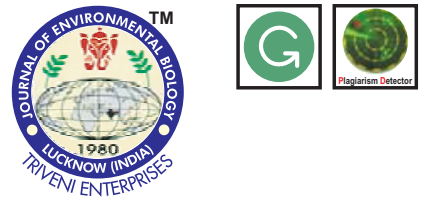

\title{
Development of sooty moulds in mango orchards in relation to weather parameters and major sucking pests
}

\section{Authors Info}

P.K. Shukla ${ }^{1 *}$, Gundappa ${ }^{1}$ and

T. Adak

${ }^{1}$ Crop Protaction Devision,

ICAR- Central Institute for

Subtropical Horticulture,

Rehmankhera, Lucknow-226 101, India

${ }^{2}$ Division of Crop Production,

ICAR- Central Institute for

Subtropical Horticulture,

Rehmankhera, Lucknow-226 101, India

*Corresponding Author Email : pksmush@gmail.com

Key words

Hopper

Mangifera indica

Sucking pests

Sooty mould

Publication Info

Paper received: 14.10 .2016

Revised received : 16.01.2017

Re-revised received: 13.02 .2017

Accepted : 09.03.2017

\begin{abstract}
Aim: Sooty moulds proliferate on mango foliage, subsisting on the honeydew created by sucking pests. It reduces photosynthetic area of tree. Factors affecting the development of sooty moulds on mango trees was studied for three consecutive seasons (2013, 2014 and 2015).
\end{abstract}

Methodology: Data were recorded at weekly interval from trees of mango cv. Dashehari of 20-35 year age selected with planting at $7.5 \mathrm{~m} \times 7.5 \mathrm{~m}$ to $10 \mathrm{~m} \times 10 \mathrm{~m}$ distances at 22 different locations in Lucknow district. Sooty moulds incidence and severity data were analyzed for relationship with sucking pest incidence and weather data.

Results: Sooty moulds incidence and severity was found to vary across the seasons. Peak incidence $(28.8 \%)$ of sooty mould was recorded during the $11^{\text {th }}$ Standard Meteorological Week (SMW) with peak severity $(14.2 \%)$ during $17^{\text {th }}$ SMW of the year 2013. During the year 2014, peak incidence (27.8) and severity $(15.6 \%)$ of sooty mould was recorded during $40^{\text {th }}$ SMW. Similarly, peak incidence $(42.5 \%)$ and severity $(27.5 \%)$ of sooty mould was recorded at $25^{\text {th }}$ SMW during the year 2015 . The higher incidence and severity of sooty mould was recorded during the year 2015 compared to 2014 and 2013. Mango hoppers peak incidence was observed during $13^{\text {th }}, 19^{\text {th }}$ and $23^{\text {rd }}$ SMW during the year 2013, 2014 and 2015. Whereas, the scale insect peak incidence was recorded during $9^{\text {th }}, 39^{\text {th }}$ and $14^{\text {th }}$ SMW during the year 2013 , 2014 and 2015 respectively. Scale insect incidence had significant positive correlation with the sooty mould incidence $(r=0.65)$ and severity $(r=0.60)$. Among the weather parameters, only rainfall had positive correlation with incidence $(r=0.35)$ and severity $(r=0.37)$ of sooty moulds. Step wise regression analysis showed that the hopper and scale insect incidence could influence the disease incidence upto $45 \%$ and severity upto $39 \%$. When significant weather factor rainfall was taken into consideration, the corresponding values increased to $51 \%$ and $47 \%$. However, scale insect incidence had exponential relationship with the incidence and severity of sooty mould.

Interpretation: The studies indicated that scale insect, hopper and rainfall together play a vital role in the development of mango sooty mould. Other weather factors did not have

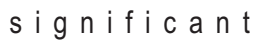
relationship with sooty mould development, but their indirect effect cannot be ruled out.

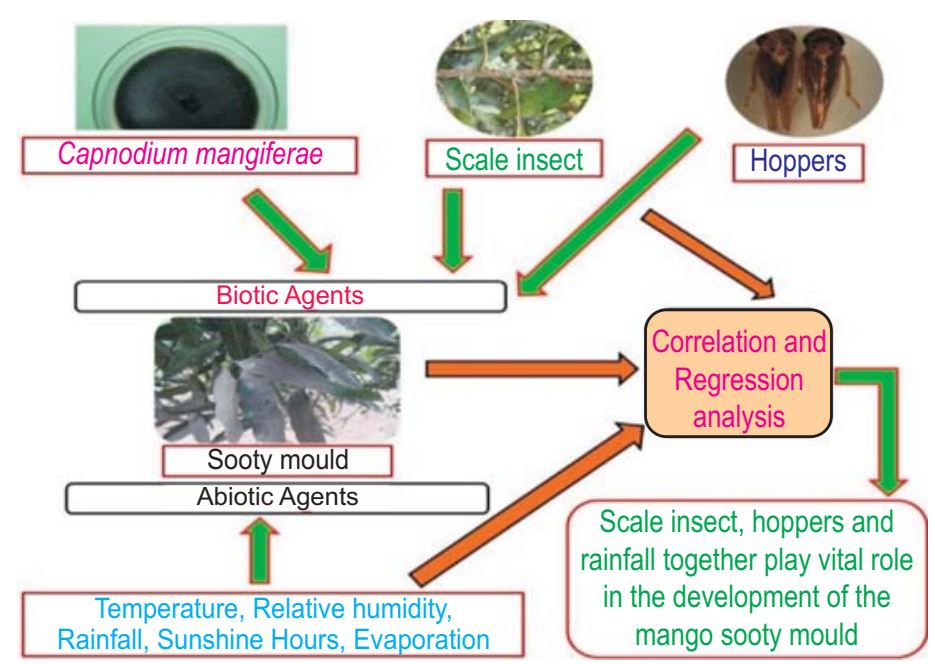




\section{Introduction}

Mango (Mangifera indica) is one of the most important fruit crops in India, cultivated over an area of 2.51 million hectares with fruit production of 18.43 million metric tonnes (NHB, 2014). Among Indian states, Uttar Pradesh ranks first with respect to production (3840.8 $\left.10 \mathrm{mt} \mathrm{ha}^{-1}\right)$ and productivity (16.4 $\mathrm{mt} \mathrm{ha}^{-1}$ ) of mango (NHB, 2014). Incidence of sooty moulds in mango orchards is very common, which not only adversely affect normal photosynthetic activity of tree but also affect aesthetic value of fruits by staining shoulder region after rains (Pitan et al., 2002; Ann et al., 2013; Rebolledo-Martínez et al., 2013; Shukla et al., 2016b). This staining is either caused due to dripping or draining of spore contaminated rain water or superficial growth of sooty moulds on epicarp (Shukla et al., 2016b). Sooty moulds also promote development of other diseases by creating highly humid environment within canopy by the capacity of mucilaginous hyphae to absorb moisture and to retain it for prolonged periods (Batista and Ciferri, 1963a,b; Lim and Khoo, 1985; Chomnunti et al., 2014). Over $50 \%$ crop losses have been recorded in heavily infested orchards (Patel et al., 2004). The growth of sooty mould is also dependent on the amount of honeydew secreted by sap sucking insects like hopper, scale and mealy bug in mango orchards (Olufemi, 2002). These sap sucking insects excrete honeydew as a waste product, which drips on the foliage below and covers leaves, twigs and even plants below with a sticky sugary coating (Udayagiri and Bigelow, 2000; Chiaradia, 2008; Jamieson, 2011; Chomnunti et al., 2014). The sooty moulds grow on this and produce a thin superficial network of dense, dark hyphae (Hughes, 1976; Faull et al., 2002). Honeydew is largely composed of sugars with smaller amounts of amino acids, proteins, minerals, vitamins and other organic compounds (Auclair, 1963). Besides growing on honeydew, sooty moulds may also obtain their food from leaf diffuse or guttation fluid (Tukey, 1971) and even from chemical contaminated rain, organic and inorganic dust particles, pollens and spores of other microflora (Lim, 1988). Thus, they proliferate during severe infestation of sucking pests and later survive with their special capabilities.

Weather and crop phenology stages are important determinant in insect and disease dynamics in mango orchards (Islam et al., 2015; Gundappa et al., 2016a,b; Shukla et al., 2016a,b). Maximum reproduction and population buildup of hopper is seen during flowering and fruit set periods followed by different vegetative phases (Gundappa et al., 2016b). Scale insects are observed round the year in mango orchards and are more severely influenced by weather factors than crop stages (Urías-López et al., 2010; Kumari et al., 2014; Razig, 2014; Prakash et al., 2016). Various sucking insects and weather parameters determine the development of sooty mould in mango orchards; however, relationship between insect pests, weather parameters and development of sooty moulds has not been studied in mango orchards. Unless we know about the crucial periods of sooty mould development on mango canopy it is difficult to develop management strategy. With the above background, the present study was undertaken to know the crucial periods of sooty mould development in relation to weather parameters and insect pest incidence under subtropical climatic conditions of Lucknow district.

\section{Materials and Methods}

A field experiment was conducted for three consecutive years $(2013,2014$ and 2015) in Lucknow district of Uttar Pradesh, India at 22 locations. The climate of the experimental site is semiarid subtropical with hot dry summers and cold winters. Orchards of mango CV. Dashehari of 20-35 year age were selected with planting spacing of at $7.5 \mathrm{~m} \times 7.5 \mathrm{~m}$ to $10 \mathrm{~m} \times 10 \mathrm{~m}$ distance. Data were recorded on weekly basis from five trees in each orchard. Incidence and severity of sooty mould was recorded from 10 shoots each in four different directions of the tree. Sooty mould incidence was calculated on the basis of the ratio of the number of shoots having sooty mould symptoms and total number of shoots observed on a tree (Naik and Lakkund, 1997). The severity of sooty mould infestation was observed on the basis of per cent area infested and it was recorded at $0-4$ scale, where, $0=$ nil, $1=$ $1-10 \%, 2=11-25 \%, 3=26-50 \%, 4=>50 \%$ (NICRA Manual, 2012). The per cent infestation index (PII) was worked out using the formula described by Wheeler (1969).

Population of hopper was counted by tapping panicles as well sweeping with insect net and recorded as number per panicle or per sweep. Similarly, population of mealy bug was recorded by visual counting on panicles of $10 \mathrm{~cm}$ length. Infestation of scale insects was recorded as number of infested shoot out of five shoots (NICRA manual, 2012). Daily weather data of temperature (maximum and minimum), relative humidity (morning and evening), rainfall, wind speed, bright sunshine hours and evaporation rates were recorded in the Agromet Observatory located within the experimental site. Data analysis was carried out using SPSS (Version 16.0).

\section{Results and Discussion}

Incidence and severity of mango sooty mould : Observations on incidence and severity of sooty mould in mango orchards made for three consecutive seasons (2013-2015) indicated that its occurrence was observed throughout the year. Higher incidence and severity of the sooty mould was recorded during the year 2015 as compared to 2014 and 2013. During the year 2013 , peak incidence $\left(28.8 \%\right.$ ) was recorded during the $11^{\text {th }}$ SMW and peak severity (14.2\%) was recorded during $17^{\text {th }}$ SMW. During the year 2014, peak incidence (27.8\%) and severity (15.6\%) of the sooty mould was recorded during $40^{\text {th }}$ SMW. Similarly, peak incidence $(42.5 \%)$ and severity $(27.5 \%)$ of the sooty mould was recorded at $25^{\text {th }}$ SMW during the year 2015 (Fig. 1 and 2). 
Incidence of mango hopper and scale insect : Mango hopper incidence was observed throughout the year in all three seasons under study (2013-2015). Peak incidence of hoppers was observed during $13^{\text {th }}, 19^{\text {th }}$ and $23^{\text {rd }}$ SMW during the year 2013
2014 and 2015 respectively (Fig. 3). Scale insect incidence was also observed throughout the year, its peak incidence was recorded during $9^{\text {th }}, 39^{\text {th }}$ and $14^{\text {th }}$ SMW during the year 2013, 2014 and 2015 respectively (Fig. 4). In general, hoppers remain active

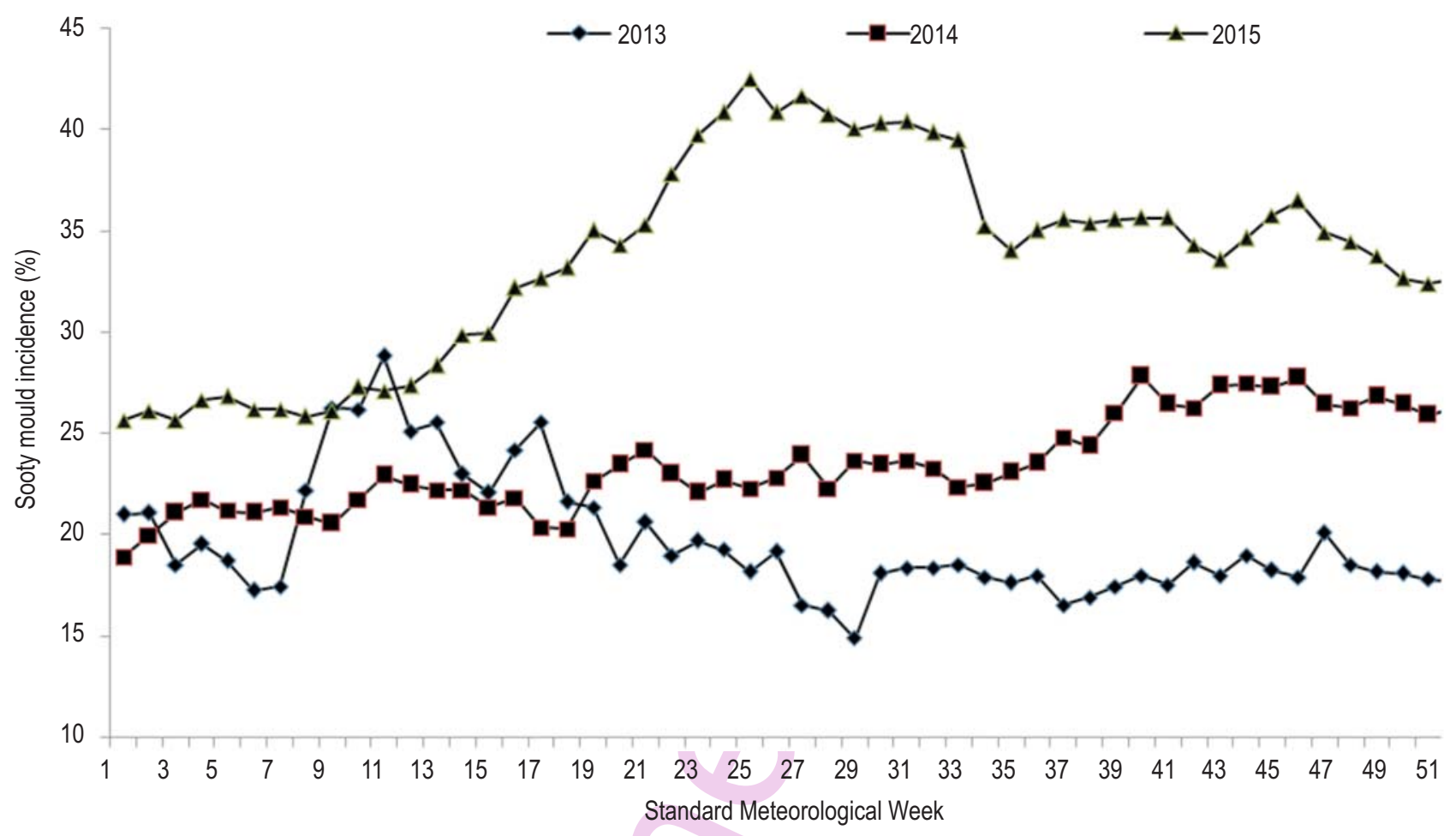

Fig. 1 : Mango sooty mould incidence during 2013 to 2015

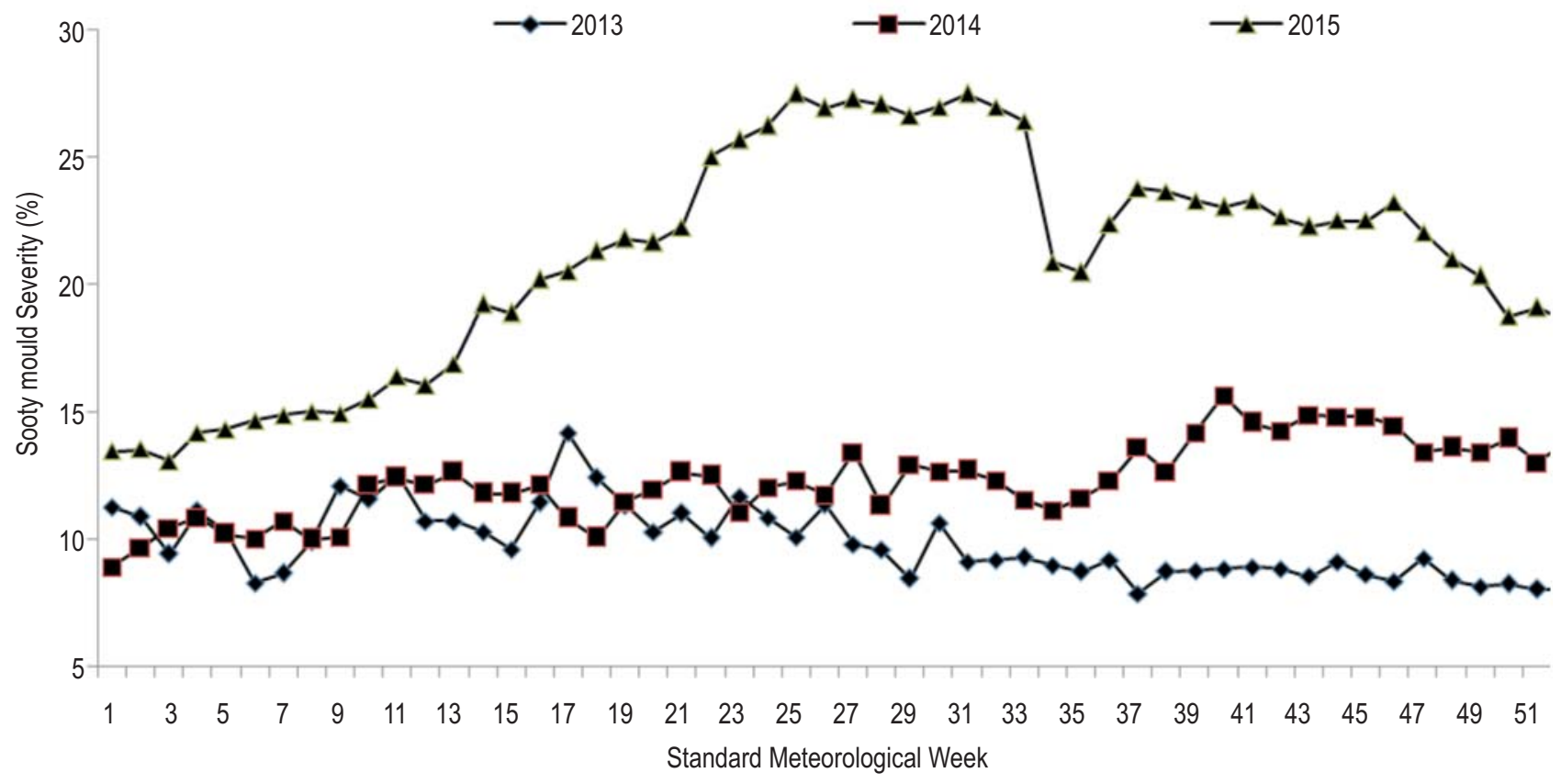

Fig. 2 : Mango sooty mould severity during 2013 to 2015 
throughout the year in cracks and crevices of mango trunk, but they were recorded on twigs when young leaves and inflorescence were available (Gundappa et al., 2014). Patel et al. (1994) reported that hopper population starts increasing with the beginning of the flowering season in the month of January to June and adults population build up was seen from March onwards and a gradual fall from July onwards. Similarly in the present study, peak occurrence of the population was between second week of March to last week of May. However, two distinct peaks were observed between reproductive stage (inflorescence

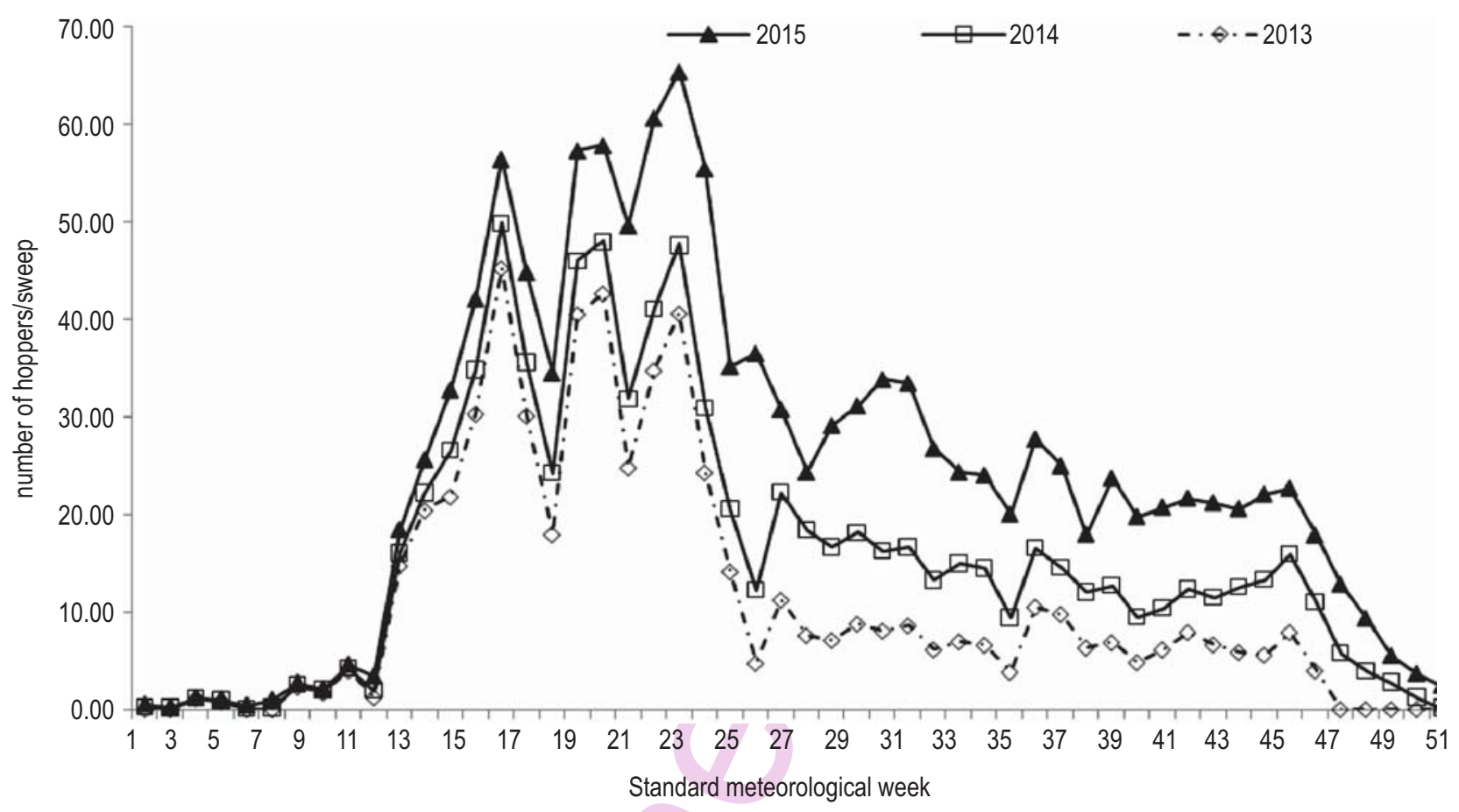

Fig. 3 : Mango hopper incidence during the year 2013 to 2015

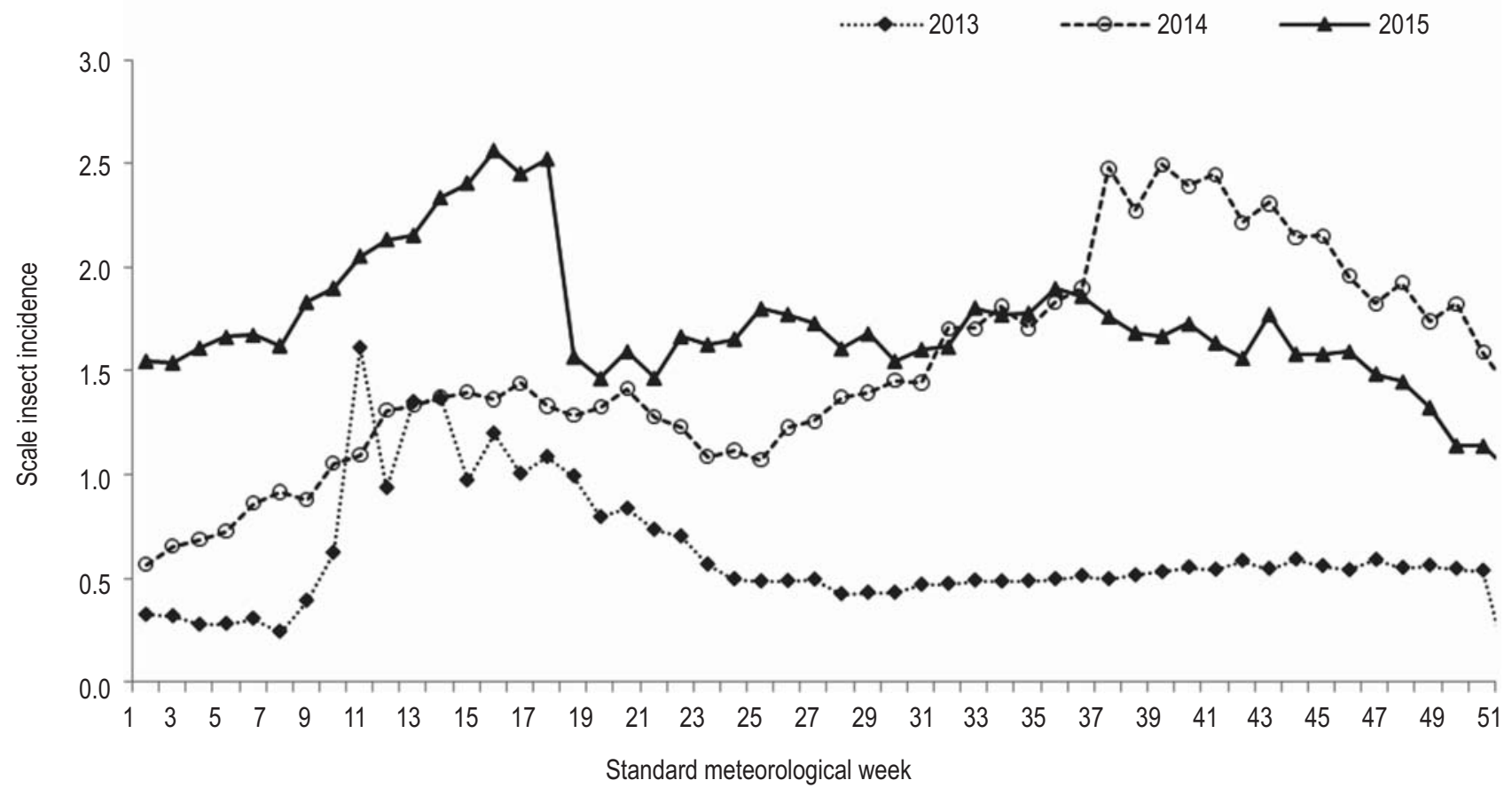

Fig. 4 : Mango scale insect incidence during the year 2013 to 2015 
Table 1: Correlation between sooty mould incidence and severity with hopper incidence, scale incidence and weather parameters

\begin{tabular}{|c|c|c|c|c|c|c|c|c|c|c|c|c|}
\hline & Hopper & Scale & $\begin{array}{l}\text { SM } \\
\text { incidence }\end{array}$ & $\begin{array}{l}\text { SM } \\
\text { severity }\end{array}$ & Tmax & Tmin & RH max & RH min & SS & WS & RF & Evp \\
\hline Hopper & 1 & & & & & & & & & & & \\
\hline Scale & -0.02 & 1.00 & & & & & & & & & & \\
\hline SM Incidence & 0.17 & 0.65 & 1.00 & & & & & & & & & \\
\hline SM Severity & 0.18 & 0.60 & 0.98 & 1.00 & & & & & & & & \\
\hline Tmax & 0.62 & 0.19 & 0.20 & 0.25 & 1.00 & & & & & & & \\
\hline Tmin & 0.49 & 0.13 & 0.16 & 0.24 & 0.82 & 1.00 & & & & & & \\
\hline RHmax & -0.42 & -0.10 & -0.18 & -0.18 & -0.63 & -0.23 & 1.00 & & & & & \\
\hline RHmin & -0.21 & -0.15 & -0.11 & -0.06 & -0.32 & 0.25 & 0.66 & 1.00 & & & & \\
\hline SS & 0.46 & 0.20 & 0.15 & 0.14 & 0.67 & 0.26 & -0.68 & -0.71 & 1.00 & & & \\
\hline WS & 0.38 & -0.04 & -0.01 & 0.02 & 0.40 & 0.51 & -0.22 & 0.05 & 0.21 & 1.00 & & \\
\hline $\mathrm{RF}$ & 0.05 & 0.15 & 0.35 & 0.37 & 0.06 & 0.27 & 0.20 & 0.34 & -0.24 & 0.23 & 1.00 & \\
\hline Evp & 0.47 & 0.29 & 0.11 & 0.13 & 0.81 & 0.68 & -0.59 & -0.27 & 0.54 & 0.44 & -0.02 & 1 \\
\hline
\end{tabular}

Table 2 : Parameter estimates and test statistics from mango hopper and scale insect incidence on the incidence and severity of sooty mould models

\begin{tabular}{|c|c|c|c|c|c|c|c|c|}
\hline Parameter & Intercept & Hopper & Scale & Rainfall & S.E. & $\mathbf{F}$ & $\mathbf{R}^{2}$ & Adj. $R^{2}$ \\
\hline Hopper v/s incidence & 24.47 & 0.13 & - & - & 6.84 & $4.67^{* *}$ & 0.02 & 0.02 \\
\hline Hopper v/s severity & 13.42 & 0.12 & - & - & 5.47 & $5.12^{*}$ & 0.03 & 0.26 \\
\hline Scale v/s incidence & 16.26 & - & 7.25 & - & 5.29 & $110.71^{* *}$ & 0.42 & 0.41 \\
\hline Scale v/s severity & 7.47 & - & 5.35 & - & 4.46 & $84.92^{\star *}$ & 0.36 & 0.35 \\
\hline Rainfall $v /$ s incidence & 23.34 & - & - & 0.18 & 6.69 & $23.01^{* *}$ & 0.26 & 0.25 \\
\hline Rainfall v/s severity & 12.84 & - & - & 0.15 & 5.16 & $25.30^{* *}$ & 0.28 & 0.27 \\
\hline Hopper and scale v/s incidence & 15.00 & 0.15 & 2.29 & & 5.15 & $63.16^{\star *}$ & 0.45 & 0.45 \\
\hline Hopper and scale v/s severity & 6.42 & 0.12 & 5.39 & & 4.35 & $49.32^{\star *}$ & 0.39 & 0.38 \\
\hline Hopper, scale and rainfall v/s incidence & 15.02 & 0.14 & 6.87 & 0.11 & 4.89 & $52.74^{* *}$ & 0.51 & 0.50 \\
\hline Hopper, scale and rainfall v/s severity & 6.43 & 0.11 & 5.01 & 0.09 & 4.09 & $44.17^{\star \star}$ & 0.47 & 0.47 \\
\hline
\end{tabular}

emergence, flowering, fruit set and fruit development) and an initiation to next season vegetative growth. Scale insect incidence was observed throughout the year in the mango orchard, however their peak incidence varied across the three seasons. Labuschagne et al. (1995) also reported that the peaks of mango scale population occurred at different periods of the year in two different place in South Africa. They also reported that scale insect population fluctuation was influenced by temperature and relative humidity.

Relationship between insect pest incidence and weather parameter with incidence and severity of mango sooty mould : Pearson correlation analysis between hopper, scale and weather parameters with incidence and severity of mango sooty mould reveled that scale incidence had significant positive correlation with the sooty mould incidence $(r=0.65)$ and severity $(r=0.60)$. However, hopper incidence had low positive correlation with incidence $(r=0.17)$ and severity $(r=0.18)$ of the sooty mould. Among the weather parameters, rainfall had positive correlation with incidence $(r=0.35)$ and severity $(r=0.37)$ of the sooty mould. Similarly, maximum temperature also had positive correlation with incidence $(r=0.20)$ and severity $(r=0.25)$ of the sooty mould
(Table 1). Effect of temperature on sooty mould development was although not significant but its effect on hopper population ( $r$ $=0.62$ ) had significant role which ultimately affected sooty mould development. Significant relationships have been established between sooty mould and weather parameters particularly temperature, rainfall and relative humidity on a number of crops (Mondal and Timmer, 2002; Chowdhury and Hossain, 2011). A positive correlation of sooty mould with temperature, negative with relative humidity and positive with rainfall was recorded by Islam et al. (2015). Similarly, the role of weather variables on the disease development across different fruit crops was reported by Awasthi et al. (2005). Chomnunti et al. (2014) reported that sooty moulds are more severe in warm climatic conditions like tropical and subtropical environment and may apparently grow faster under extreme climatic conditions.

Step wise regression analysis showed the hopper and scale insect incidence could influence the sooty mould incidence up to $45 \%$ and severity up to $39 \%$. When significant weather factor rainfall was taken into consideration, the corresponding values increased to 51 and $47 \%$ (Table 2). However, scale insect incidence showed exponential relationship with the incidence and 


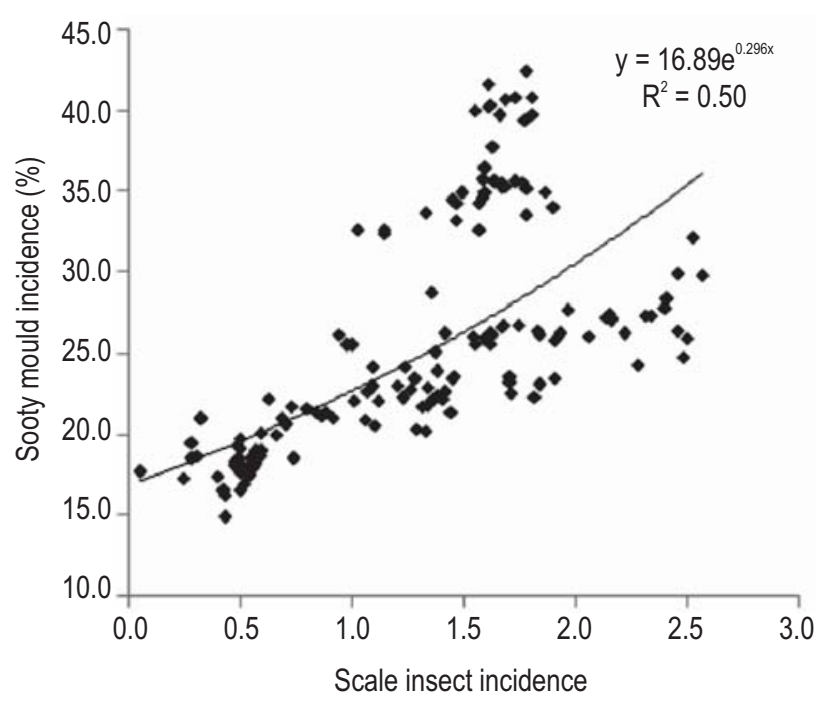

Fig. 5 : Relationship between scale insect incidence and sooty mould incidence on mango

severity of sooty mould (Fig. 5 and 6). Thus, the present study indicated scale insect, hopper and rainfall together play a vital role in the development of sooty mould.

Hopper population development trend particularly followed trend of sooty mould development during flowering and fruiting period i.e., during $10^{\text {th }}$ to $25^{\text {th }}$ SMW. Similarly, the population development of scale insects was matched with trend of sooty mould development during complete years 2013-2015. This direct effect of hopper and scale insect population on sooty mould development recorded in this observation is similar to the previous findings regarding development of sooty mould by insect generated honeydew (Chomnunti et al., 2014; Olufemi, 2002; Lim, 1988; Jamieson, 2011; Chiaradia, 2008; Udayagiri and Bigelow, 2000).

Slighter increase in severity of sooty mould during $1^{\text {st }}$ to $13^{\text {th }}$ SMW even after increasing activity and population development of hopper, mealy bugs and scale insects and fresh growth of sooty moulds was mainly due to crop phenology changes. At one hand fresh new leaves and panicles were developing and on the other hand old infested leaves were shed at increased rate during this period and ultimately, despite fresh growth of fungus on tree canopy total sooty mould covered area was almost constant.

Sooty mould severity attained peaks during $17^{\text {th }}, 40^{\text {th }}$ and $25^{\text {th }}$ SMW during the years 2013 to 2015 and development of these peaks took place during $11^{\text {th }}$ to $25^{\text {th }}$ and $35^{\text {th }}$ to $40^{\text {th }}$ SMW. It was the period during March to June when hopper and scale populations were developing fast on panicles and new vegetative flush with moderate weather; and during September to October when scale population was especially high with moderate

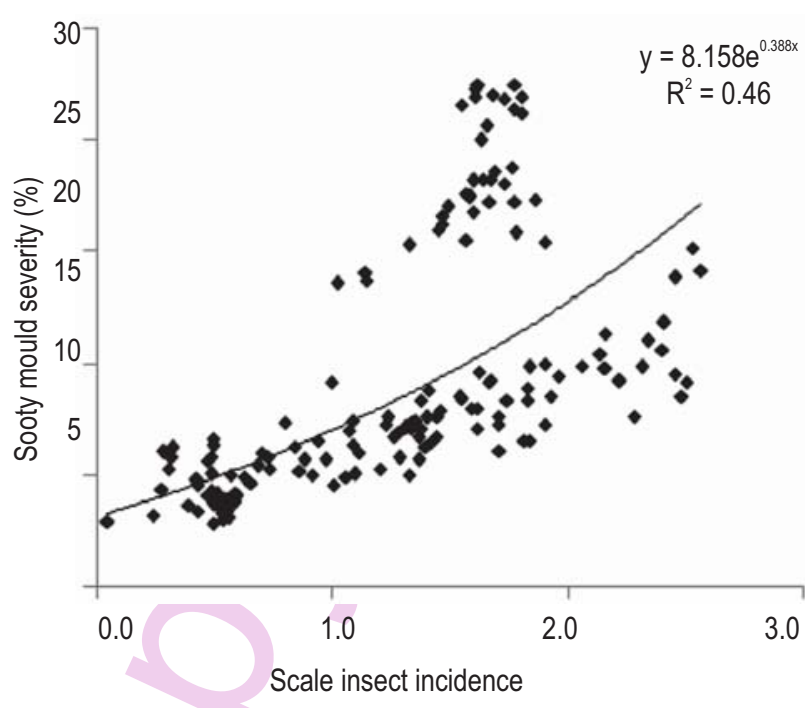

Fig. 6 : Relationship between scale insect incidence and sooty mould severity on mango

weather. It is also evident that sooty mould severity remained constant or decreased during rainy season (during $26^{\text {th }}$ to $34^{\text {th }}$ SMW) and then it was further increased during post rainy season. This is supported by the findings of Batista and Ciferri $(1963 a, b)$ that the frequency of sooty moulds appears to be greater after rainy season as the honey dew may be wash off leaves during heavy rains, while it persists for long periods during dry periods. This view is also supported by total amount of rain (1025, 753 and $617 \mathrm{~mm})$ and sooty mould incidence (19.7, 23.5 and $33.6 \%)$ and severity $(9.8,12.3$ and $20.9 \%)$ during consecutive years 2013 , 2014 and 2015. Gradual decrease in sooty mould severity recorded after $40^{\text {th }}$ SMW may be due to dry season and decreasing temperature. At this stage, the old growth of sooty moulds may gradually exhaust honeydew sugars on plant surface and mycelium be starved and also may die during dry season. Crop phenology factors might have also affect the sooty mould severity without actual change in sooty mould infestation. Several vegetative flushes are seen on mango trees every year. Such phenophases not only influence insect population but also alter total sooty mould covered leaf area on tree.

The observations indicated that the development of sooty moulds in mango orchards is directly influenced by the production of honeydew by sucking pests, rainfall, temperature and phenological changes. Role of any single factor other than weather factors (temperature, relative humidity, rainfall, sunshine, winds and evaporation rate), insect population (hopper, mealy bug and scale) and crop phenology could not be ruled out in this study. Rapid development of sooty moulds was recorded during the months of February to June and September to October and this period was identified as crucial period for sooty mould management. 


\section{Acknowledgments}

Authors are thankful to the Director, CISH, Lucknow for providing facilities for carrying out the work. Thanks are also due to Indian Council of Agricultural Research, New Delhi for providing financial assistance under National Initiative of Climate Resilient Agriculture (NICRA) Project entitled, "Understanding the changes in host pest interactions and dynamics in mango under climate change scenario".

\section{References}

Ann, P.J., J.N. Tsai, H.F. Ni and H.R. Yang: Current status on occurrence and management of major diseases of mango in Taiwan. Plant Pathol. Bull., 22, 67-92 (2013).

Auclair, J.L.: Aphid feeding and nutrition. Annu. Rev. Entomol., 8, 439-490 (1963).

Awasthi, D.P., S. Sarkar, N.K. Mishra and S.A.K.M. Kaisar: Disease situation of some major fruit crops in new alluvial plains of west Bengal. Environ. Ecol., 235, 497-499 (2005).

Batista, A.C. and R. Ciferri: The sooty-moulds of the family asbolisiaceae. Quad. Ist Bot. Univ. Lab. Crittogam Pavia, 31, 229 (1963b)

Batista, A.C. and R. Ciferri: Capnodiales. Saccardoa, 2, 296 (1963a)

Chiaradia, L.A., J.M. Milanez, M.A. Smaniotto and M.R.F. Davila: Population fluctuation and capture height of Diaphorina citri in citrus orchard. Revista de Ciencias Agroveterinarias, 7, 157-159 (2008).

Chomnunti, P., S. Hongsanan, B. Aguirre-Hudson, Q. Tian, D. Peršoh, K. Manpreet, M.K. Dhami, A.S. Alias, J. Xu, X. Liu, M. Stadler and K.D. Hyde: The sooty moulds. Fungal Diversity, 66, 1-36 (2014).

Chowdhury, M.S.M. and I. Hossain: Effects of temperature, rainfall and relative humidity on leaf spot of jackfruit seedling and its ecofriendly management. The Agriculturists, 9, 126-136(2011).

Faull, J.L., I. Olejnik, M. Ingrouille and D. Reynolds: A reassessment of the taxonomy of some tropical sooty moulds. Trop. Mycol., 2, 33-40 (2002).

Gundappa, P.D., K. Jayanthi and A. Verghese: Migratory behavior of mango hopper, Idioscopus spp. in relation to host plant flowering phenology:A synchronous shift. An Int. J. Life Sci.: The Bioscan, 9, 639-641 (2014).

Gundappa, T. Adak and P.K. Shukla: Prediction of mango thrips using thermal indices. GERFBull. Biosci., 7, 17-20 (2016a).

Gundappa, T. Adak and P.K. Shukla: Seasonal dynamics of mango hoppers and their management under subtropics. GERF Bull. Biosci., 7, 6-9 (2016b).

Hughes, S.J.: Sooty moulds. Mycologia, 68, 693-820 (1976).

Islam, M.N., K.K. Poddar, I. Hossain, M.S.M. Chowdhury, A.F.M. Jamal Uddin and $\mathrm{H}$. Mehraj: Relationship of mango seedling diseases prevalence to the environmental factors. Scientia Agriculturae, 10, 137-144 (2015).

Jamieson, L.E., N.E.M. Page-Weir and K. Pyle: Targeted insecticides to control Australian citrus whitefly (Orchamoplatus citri). New Zealand Plant Protection Society's Annual Conference, Rotorua, New Zealand, pp.93-100 (2011).

Kumari, D.A., V. Anitha and B.K.M. Lakshmi: Evaluation of insecticides for the management of scale insect in mango (Mangifera indica). Int. J. Plant Prot., 7, 64-66 (2014).
Labuschagne, T.I., H. Van Hamburg and I.J. Froneman: Population dynamics of the mango scale, Aulacaspis tubercularis (Newstead) (Coccoidea: Diaspididae) in South Africa. Israel J. Entomol., 29, 207-217 (1995).

Lim, T.K. and K.C. Khoo: Diseases and disorders of mango in Malaysia. Tropical Press, Kuala Lumpur (1985).

Lim, T.K.: Studies on some sooty moulds on guava in Malaysia. Pertanika, 11, 349-355 (1988).

Mondal, S.N. and L.W. Timmer: Environmental factors affecting pseudothecial development and ascospore production of Mycosphaerella citri, the causal agent of citrus greasy spot. Phytopathology, 92, 1267-1275(2002).

Naik, S.T. and L. R. Lakkund: Diagrammatic representation of leaf area damage in tar spot of Dalbergia latifolia. Indian Forestry, 124, 1057-1058 (1997).

NHB Database: National Horticulture Board, Department of Horticulture and Cooperation, Government of India, Aristo Printing Press, New Delhi, p. 4 (2014).

NICRA team of Mango Pest Surveillance: Manual for Mango Pest Surveillance. Jointly published by National Centre for Integrated Pest Management, New Delhi, ICAR Research Complex for Eastern Region, Research Centre, Ranchi, Central Research Institute for Dryland Agriculture, Hyderabad and Central Institute for Subtropical Agriculture, Lucknow, p. 39 (2012).

Olufemi, O.R., P.G. Mwansat, O.S.A. Sunday, S.A. Oyeboade and A.A. Taiwo: Effect of mango mealybug and sooty mould attack on mango and the impact of the released Gyranusoidea tebygi Noyes on yield. Fruits, 57, 105-113 (2002).

Patel, J.R., A.M. Shekh and H.C. Ratanpara: Seasonal incidence and effect of minimum temperature and vapour pressure on the population of mango hoppers in middle Gujarat. Gujarat Agric. Univ. J., 20, 5-8 (2004).

Patel, J.R., A.M. Shekh and H.C. Ratanpara: Seasonal incidence and effect of minimum temperature and vapour pressure on the population of mango hoppers in middle Gujarat. Guj. Agric. Uni. Res. J., 20, 5-8 (1994).

Pitan Olufemi, O.R., M. Georgina, O.S.A. Sunday, S.A. Oyeboade and A. Akinlosotu Taiwo: Effect of mango mealybug and sooty mould attack on mango and the impact of the released Gyranusoidea tebygi Noyes on yield. fruits., 57, 105-113 (2002).

Prakash, R., R. Patil, P.S. Hugar, V.I. Benagi and J.C. Mathad: Status and incidence of scale insect, Hemilecanium imbricans (Green) (Coccidae: Homoptera) on mango and other host plants in few districts of Karnataka. J. Exp. Zool., India, 19, 883-889 (2016).

Razig, A.A.M.A.: Survey for identification and incidence evaluation of dominant pests on mangoes Mangifera indica (L.) in some parts of southern Sinnar State, Sudan. Persian Gulf Crop Protec., 3, 1-5 (2014).

Rebolledo-Martínez, A., A.L. Del Angel-Pérez, P.A. Nain and D.P. Gabriel: Sooty mould control (Capnodium mangiferae Cooke and Brown) with biofungicides in leaves and fruits of mango "Manila". Trop. Subtro. Agroecosyst., 16, 355-362 (2013).

Shukla, P.K., T. Adak and Gundappa: Seasonal dynamics of powdery mildew of mango and its management under subtropics. GERF Bull. Biosci., 7, 21-25 (2016a).

Shukla, P.K., T. Adak, A.K. Misra and A. Singh: Appraisal of shoulder browning disease of mango (Mangifera indica L.) in subtropical region of India. J. Mycol. Plant Pathol., 46, 38-46 (2016b).

Tukey, H.B. Jr.: Leaching of substances from plants. In: Ecology of Leaf 
Surface Microorganisms (Eds. T.F. Preece and C.H. Dickinson). Academic Press, London and New York, pp. 39-53 (1971).

Udayagiri, S. and R. Bigelow: Potential for biological control of the greenhouse whitefly in the field with Encarsia formosa: the strawberry experience. In: California Conference on Biological Control II (Eds: M.S. Hoddle). The Historic Mission Inn Riverside, California, USA, pp.191-194 (2000).
Urías-López, M.A., J.A. Osuna-García, V. Vázquez-Valdivia and M.H. Pérez-Barraza: Population dynamics and distribution of the white mango scale (Aulacaspis tubercularis Newstead) in Nayarit, Mexico. Revista Chapingo. Serie Horticultura, 16, 77-82 (2010).

Wheeler, B.E.J.: An Introduction to Plant Diseases. John Wiley and Sons Limited, London (1969). 